\title{
Penyusunan dan Pelaksanaan Anggaran dalam Konteks Pengembangan Usaha (Studi pada Bakso dan Mie Ayam Mas Hadi “Asli Solo")
}

\section{Preparation and Implementation of the Budget in the Context of Business Development (Study on Meatballs and Chicken Noodles Mas Hadi “Asli Solo")}

\author{
Devi Agustin ${ }^{1)}$, Bambang Ismanto ${ }^{2)}$, Destri Sambara Sitorus ${ }^{3)}$ \\ ${ }^{1,2,3)}$ Fakultas Keguruan dan Ilmu Pendidikan, Universitas Kristen Satya Wacana, Salatiga \\ e-mail korespondensi:162016019@student.uksw.edu
}

\begin{tabular}{|l|}
\hline Info Artikel \\
\hline Riwayat Artikel : \\
Diterima: 14 April 2020 \\
Disetujui: 01 Juni 2020 \\
Dipublikasikan: Januari 2021 \\
\hline Nomor DOI \\
10.33059/jseb.v12i1.2240 \\
Cara Mensitasi : \\
Agustin, D., Ismanto, B., \& \\
Sitorus, D. S. (2021). \\
Penyusunan dan pelaksanaan \\
anggaran dalam konteks \\
pengembangan usaha (Studi \\
pada bakso dan mie ayam Mas \\
Hadi “Asli Solo”). Jurnal \\
Samudra Ekonomi dan Bisnis, \\
12(1), 35-45. doi: 10.33059/ \\
jseb.v12i1.2240.
\end{tabular}

\begin{abstract}
Abstrak
Anggaran menyajikan informasi mengenai rencana pengeluaran dan pendapatan yang dinyatakan dalam satuan rupiah untuk periode yang akan datang. Penelitian ini bertujuan untuk menganalisis proses penyusunan dan pelaksanaan anggaran dalam pengembangan usaha Bakso dan Mie Ayam Mas Hadi "Asli Solo". Jenis penelitian adalah metode deskriptif kualitatif. Teknik pengumpulan data dengan pengamatan, studi dokumentasi dan wawancara. Analisis data dilakukan melalui tahapan reduksi, display dan verifikasi data. Untuk meningkatkan kepercayaan (triangulasi) data dilakukan penelitian ulang dan uji-silang sumber penelitian. Hasil penelitian menunjukkan bahwa tujuan pengembangan usaha dilakukan untuk memperkenalkan produk kepada masyarakat dan memperoleh laba sebanyak-banyaknya. Proses penyusunan dan pelaksanaan anggaran dalam rangka pengembangan usaha terdapat beberapa tahap yang sudah sesuai, namun ada yang belum sesuai dengan tahapan tersebut. Komponen anggaran pada obyek penelitian meliputi tempat, peralatan dan perlengkapan.
\end{abstract}

Kata Kunci: Penyusunan Anggaran, Pelaksanaan Anggaran, Pengembangan Usaha.

\begin{tabular}{l}
\hline Article Info \\
\hline Article History: \\
Received: 14 April 2020 \\
Accepted: 01 June 2020 \\
Published: January 2021 \\
\hline DOI Number : \\
10.33059/jseb.v12i1.2240 \\
How to cite: \\
Agustin, D., Ismanto, B., \& \\
Sitorus, D. S. (2021). \\
Penyusunan dan pelaksanaan \\
anggaran dalam konteks \\
pengembangan usaha (Studi \\
pada bakso dan mie ayam Mas \\
Hadi “Asli Solo”). Jurnal \\
Samudra Ekonomi dan Bisnis, \\
12(1), 35-45. doi: 10.33059/ \\
jseb.v12i1.2240.
\end{tabular}

Abstract

The budget presents information about expenditure and income plans expressed in rupiah units for the coming period. This study aims to analyze the process of preparing and implementing the budget in developing the business of Meatballs and Chicken Noodles Mas Hadi "Asli Solo". This qualitative-descriptive research was collecting data through observation, documentation and interviews. Data analysis was carried out through the stages of reduction, display and data verification. To increase the confidence (triangulation) of data, a repeat research and cross-check of research sources was conducted. The results showed that the purpose of business development was carried out to introduce the product to the community and obtain as much profit as possible. There are several stages of preparation and implementation process of budget in the context of business development that are appropriate, but some are not yet in accordance with. Budget components of the research object include place, equipment and supplies.

Keywords: Budget Preparation, Budget Implementation, Business Development. 


\section{PENDAHULUAN}

Sebagai sebuah subyek ekonomi, perkembangan usaha mikro, kecil dan menengah sangat menjadi perhatian dalam perekonomian makro. Perkembangan usaha memberi dampak pada struktur perekonomian menjadi kuat. Secara riil, terdapat penyerapan tenaga kerja, permintaan dan pertumbuhan investasi serta meningkatkan daya beli masyarakat (Suci, 2017). Selain itu, akan meningkatkan daya saing dan mempertahankan keberlangsuangan usaha.

Pada saat pelaksanaan pengembangan usaha, seringkali pelaku usaha mengalami kesulitan. Usaha mikro, kecil dan menengah memiliki permasalahan yang cukup kompleks dimana permasalahan itu menjadi kelemahan dan keterbatasan dalam mengelola usaha (Darwanto, 2013; Suci, 2017). Permasalahan tersebut meliputi keterbatasan modal, sumber daya yang belum memadai serta kesulitan dalam pelaksanaan aktivitas pemasaran. Strategi pengembangan usaha yang tepat dapat mengatasi permasalahan.

Pengembangan usaha dapat berjalan dengan sukses apabila memiliki penyusunan anggaran yang baik. Karena di dalam proses penyusunan anggaran memuat fungsi-fungsi manajemen yaitu perencanaan, pengorganisasian, menggerakkan dan mengontrol. Hal ini didukung dengan pendapat Meiliani (2016) yang menyatakan bahwa jika suatu perusahaan tidak menyusun anggaran maka akan menghadapi kesulitan saat menjalankan kegiatan perusahaannya. Oleh sebab itu, penyusunan anggaran bertujuan untuk merinci segala sesuatu yang diperlukan dalam kegiatan perusahaan yang akan dicapai serta memudahkan dalam pengawasan. Penyusunan anggaran yang salah akan memberikan dampak negatif dalam pengembangan usaha.

Bakso dan Mie Ayam Mas Hadi “Asli Solo" merupakan salah satu usaha yang bergerak di bidang makanan. Selain menjual makanan, usaha ini juga melakukan produksi sendiri. Selama 25 tahun berdiri, usaha ini tidaklah mudah dalam upaya bertahan dan berkembang. Keunggulan usaha bakso dan mie ayam ini dibandingkan usaha sejenis yang lain adalah pemilik mempromosikan tempat produksinya dan selalu mengajak pelaku usaha lain untuk menjaga kebersihan tempat produksi serta menjaga kualitas produknya.

Pada tahun 1996 Bakso dan Mie Ayam Mas Hadi “Asli Solo"membuka usaha yang bertempat di kios dalam Pasar Babadan dan memiliki beberapa kompetitor diantaranya Bakso Kondang, Bakso Pak Tekno, Bakso Pak Slamet, serta Bakso dan Mie Ayam Pak Darto. Dari beberapa kompetitor tersebut, hanya Bakso dan Mie Ayam Pak Darto yang masih bertahan namun usaha itu tidak memiliki cabang usaha. Usaha Bakso dan Mie Ayam Mas Hadi "Asli Solo" hingga saat ini masih tetap eksis ditengah para kompetitor lainnya. Tabel 1 menunjukkan perkembangan usaha dari para kompetitor Bakso dan Mie Ayam Mas Hadi "Asli Solo".

Fenomena yang mendasari masalah di dalam penelitian ini adalah bagaimana tujuan pengembangan usaha Bakso dan Mie Ayam "Asli Solo". Secara lebih spesifik, tujuan khusus dari penelitian ini adalah bagaimana proses penyusunan dan pelaksanaan anggaran dalam konteks pengembangan usaha, serta bagaimana komponen anggaran di dalam konteks pengembangan usaha pada Bakso dan Mie Ayam Mas Hadi “Asli Solo”.

Berdasarkan latar belakang yang telah dipaparkan, maka penelitian ini bermaksud mengeksplorasi tujuan pengembangan usaha, proses penyusunan dan pelaksanaan anggaran serta komponen anggaran dalam rangka pengembangan pada usaha Bakso dan Mie Ayam Mas Hadi "Asli Solo”. 
Tabel 1. Perkembangan Kompetitor Usaha Bakso dan Mie Ayam Mas Hadi “Asli Solo"

\begin{tabular}{cccc}
\hline No. & Tahun & \multicolumn{1}{c}{ Kompetitor } & Perkembangan \\
\hline 1. & 1996 & Bakso Kondang & Gulung tikar \\
& & Bakso Pak Tekno & Gulung tikar \\
& & Bakso Pak Slamet & Masih tikar \\
& & Bakso Mie Ayam Pak Darto & Gulung tikar \\
\hline 2 & 2002 & Bakso Kondang & Gulung tikar \\
& & Bakso Pak Tekno & Gulung tikar \\
& Bakso Pak Slamet & Masih ada \\
\hline 3 & Bakso Mie Ayam Pak Darto & Masih ada \\
& Bakso Warung Doyong & Masih ada \\
& & Simpatik - Mie Ayam \& Bakso & Masih ada \\
& Mie Lovers Mie Ayam Enak & Masih ada \\
& Bakso Ciamik & Masih ada \\
& Mie Ayam Bakso Suradi & Masih ada \\
& Bakso Ijo & Masih ada \\
& Mie Ayam \& Bakso Pak Ndut & Masih ada \\
\hline 4 & Mie Ayam Pangsit \& Bakso Pak Petruk & Masih ada \\
& 2013 & Bakso Malang Mak Nyooss & Masih ada \\
\hline
\end{tabular}

Sumber: Diolah penulis, 2020.

\section{Usaha Mikro, Kecil dan Menengah (UMKM)}

Berdasarkan Undang-Undang Republik Indonesia No. 20 Tahun 2008 tentang Usaha Mikro, Kecil dan Menengah (UMKM) mengklasifikasi usaha berdasarkan sejumlah kriteria. Usaha mikro diklasifikasikan berdasarkan dua kriteria, yaitu memiliki nilai kekayaan bersih maksimal Rp. 50.000.000,(diluar tanah dan bangunan tempat usaha); serta memiliki volume atau hasil penjualan per tahun maksimal Rp. 300.000.000.000,-. Usaha kecil memiliki nilai kekayaan di atas Rp. 50.000.000,- sampai Rp. 500.000.000,(diluar tanah dan bangunan tempat usaha), serta volume atau hasil penjualan per tahun di atas Rp 300.000.000,- hingga mencapai Rp. 2.500.000.000,-.

Selanjutnya, usaha diklasifikasikan berskala menengah jika memiliki nilai kekayaan di atas Rp. 500.000.000,- hingga mencapai Rp. 50.000.000.000,- diluar aset tanah dan bangunan tempat usaha, serta volume hasil penjualan tahunan di atas Rp. 2.500.000.000,hingga Rp. 50.000.000.000,-. Terakhir, suatu usaha terklasifikasi skala besar jika memiliki nilai kekayaan bersih sebesar lebih dari Rp. 50.000.000.000,-. Usaha berskala besar ini meliputi milik negara atau swasta, usaha patungan dan usaha asing yang melakukan ekonomi di Indonesia.

\section{Pengembangan Usaha}

Pengembangan usaha merupakan cara atau proses memperbaiki pekerjaan dengan meningkatkan kualitas dan kuantitas produksi serta melakukan perluasan usaha dengan menggerakkan pikiran, tenaga dan badan untuk mencapai tujuan yang ditetapkan (Jannah, 2017). Pengembangan usaha dimaksudkan untuk menjadikan pelaku ekonomi yang memiliki daya saing melalui peningkatan perluasan usaha, peningkatan kualitas dan kuantitas produksi. Untuk 
mencapai tujuan, kegiatan pengembangan usaha tersebut harus melalui empat tahapan pengembangan usaha (Jannah, 2017; Suhendi \& Sasangka, 2014). Tahapan dari kegiatan pengembangan usaha yakni memiliki ide usaha, membuat sebuah konsep usaha, mengembangkan dan mengimplementasikan rencana atau konsep usaha tersebut, serta melakukan pengendalian usaha.

Menurut Shalahudin et al. (2018), upaya pengembangan usaha dapat dilakukan melalui beberapa cara. Pertama adalah perluasan skala usaha, yaitu pengembangan yang mencakup penambahan jenis produk, penambahan lokasi usaha serta penambahan mesin, tenaga kerja dan modal untuk investasi. Cara kedua adalah perluasan cakupan usaha, yaitu pengembangan yang dilakukan dengan menambah jenis usaha di lokasi baru dan menambah jenis variasi produk. Cara ketiga adalah perluasan kerjasama, pengabungan dan ekspansi. Penggabungan usaha dapat dilakukan dengan beberapa jenis usaha, yaitu joint venture, merger, holding, akuisisi, sindikat dan kartel.

\section{Anggaran}

Anggaran menyatakan rencana kegiatan suatu organisasi tertulis yang dapat yang dinyatakan dalam satuan uang untuk jangka waktu tertentu (Nafarin, 2013). Dalam hal ini, penganggaran (budgeting) adalah proses menyusun anggaran, sedangkan anggaran (budget) merupakan hasil dari penyusunan anggaran. Penyusunan anggaran bertujuan untuk menyediakan sejumlah informasi bagi pihak manajemen perusahan yang digunakan untuk pengambilan keputusan (Sasongko \& Parulian, 2010). Anggaran disusun untuk memberikan gambaran tentang kebutuhan sumber-sumber daya untuk mencapai tujuan perusahaan

Menurut Rudianto (2009), anggaran memiliki fungsi-fungsi yang berkaitan dengan pencapaian tujuan. Fungsi anggaran sebagai perencanaan menyatakan bahwa perusahaan menetapkan segala sesuatu yang berkaitan dengan apa yang ingin dicapai perusahaan. Sebagai fungsi pengorganisasian, perusahaan mencari sumber-sumber daya yang dibutuhkan untuk melaksanakan kegiatan yang telah direncanakan. Setelah sumber daya yang dibutuhkan diperoleh, maka selanjutnya dalah perusahaan mengarahkan dan mengolah setiap sumber daya yang dimiliki agar dapat bekerja secara optimal. Fungsi selanjutnya adalah pengendalian, yaitu perusahaan memastikan sumber-sumber daya yang dimiliki telah bekerja sesuai rencana dengan efektif dan efisien untuk menjamin bahwa tujuan perusahaan telah tercapai.

\section{METODE PENELITIAN}

Pendekatan yang digunakan dalam penelitian ini berdasarkan metode deskriptifkualitatif (Sugiyono, 2015; Fatchan, 2011). Dalam hal ini, peneliti mendeskripsikan serta menginterprestasikan proses penyusunan dan pelaksanaan anggaran pengembangan usaha Bakso dan Mie Ayam Mas Hadi “Asli Solo". Obyek penelitian ini adalah penyusunan dan pelaksanaan anggaran pengembangan usaha bakso dan mie ayam tersebut.

Subyek ataupun yang menjadi informan bagi penelitian ini adalah bidang penyusunan anggaran pengembangan usaha Bakso dan Mie Ayam Mas Hadi "Asli Solo". Pengumpulan data dilakukan melalui beberapa metode, yaitu pengamatan, studi dokumentasi dan wawancara. Analisis data dijalankan melalui tahapan reduksi, display, serta verifikasi/konklusi (Fuad et al., 2019; Sugiyono, 2015; Moleong, 2011). Validitas data dilakukan berdasarkan teknik triangulasi melalui per-panjangan waktu penelitian dan melakukan uji-silang (cross-check) data dari pemilik dan para karyawan. 


\section{HASIL ANALISIS}

\section{Gambaran Obyek Penelitian}

Usaha bakso dan mie ayam Mas Hadi merupakan usaha yang bergerak di bidang makanan. Usaha ini memproduksi bakso, mie ayam dan tahu bakso yang kemudian dijual sendiri. Usaha ini telah berdiri sejak tahun 1991 sampai saat ini.

Usaha ini berawal pada tahun 1991 saat beliau memulai dari berjualan keliling hingga akhirnya menetap dan membuka cabang usaha. Mas Hadi mulai menetap pada tahun 1996 dengan mengontrak los atau kios kecil di dalam Pasar Babadan dengan bermodalkan tabungan sendiri yang disisihkan sejak dari beliau berjualan keliling.

Cabang pertama usaha ini berada di di kios diluar Pasar Babadan yang masih dalam satu kompleks. Cabang pertama tersebut berdiri pada tahun 2002. Cabang kedua berada di Karangjati yang didirikan pada tahun 2009. Pada tahun 2013 warung bakso yang berada di kios dalam Pasar Babadan mengalami kebakaran, sehingga beliau harus membuat kios sementara di depan rumahnya. Kios tersebut pada akhirnya menjadi tempat menetap atau pengganti warung bakso yang sebelumnya ada di los dalam Pasar Babadan.

\section{Tujuan Pengembangan Usaha}

Ide usaha Hadi Mulyono berawal dari keinginan menjadi penjual bakso mandiri yang bercita-cita memiliki cabang-cabang usaha. Ide itu didukung dengan kegigihan beliau dalam menabung sebagai persiapan modal pengembangan usaha. Setelah dirasa memiliki modal yang cukup, beliau merealisasikan mimpinya dengan membuka beberapa cabang yang diiringi dengan peningkatkan kualitas poduk dan pelayanan.

Tujuan awal beliau mulai berjualan keliling bukanlah untuk mencari keuntungan finansial sebanyak-banyaknya, melainkan untuk memperkenalkan merek dagangnya ke masyarakat seluas-luasnya. Namun dengn seiring berjalannya waktu dan produknya sudah dikenal masyarakat, tujuan beliau mengalami perubahan menjadi berorientasi mencari laba sebanyak-banyaknya. Hal ini terlihat dari prinsip beliau bahwa dengan memiliki laba sedikit namun dikali banyak, maka laba akan menjadi lebih banyak.

\section{Proses Penyusunan Anggaran dalam Konteks Pengembangan Usaha}

Analisis terkait penyusunan anggaran pada usaha Bakso dan Mie Ayam Mas Hadi "Asli Solo" dihubungkan kepada tahapan penyusunan menurut Nafarin (2013), yang meliputi tahap penentuan pedoman anggaran, tahap persiapan anggaran, tahap penentuan anggaran, serta tahap pelaksanaan anggaran. Analisis pada masing-masing tahapan tersebut diuraikan sebagai berikut.

Tahap pertama adalah tahap penentuan pedoman anggaran. Pada tahap ini, pemilik Bakso dan Mie Ayam Mas Hadi "Asli Solo" menyusun anggaran dengan tujuan untuk melaksanakan pengembangan usaha, yakni perluasan skala usaha (penambahan cabang usaha). Asumsi yang menjadi dasar bagi penyusunan anggaran pengembangan usaha tersebut yaitu beliau mengumpulkan modal terlebih dahulu dengan cara menyisihkan pendapatan harian sedikit demi sedikit. Beliau memiliki kebijakan khusus dalam sumber dana, yakni sumber dana yang digunakan untuk pengembangan usaha adalah modal sendiri dan tidak melakukan pinjaman dari investor maupun bank. Hal ini secara tegas beliau nyatakan saat proses wawancara.

"Iya semua modal sendiri atau uang pribadi ... Pinjaman dari bank itu kan butuh bunga, butuh BPKB ... Justru karena hutang saya menjadi kere, kenapa harus memaksakan kehendak, kenapa harus mementingkan ego sendiri" (Hadi Mulyono, pemilik usaha). 
Kebijakan ini membuat pelaksanaan pengembangan usaha beliau relatif sedikit lebih lama dari usaha yang lain, sehingga beliau tidak memiliki target mengenai kapan dilakukannya upaya pengembangan usaha. Sedangkan panitia penyusunan anggaran adalah terdiri dari beliau dan keluarga inti. Keluarga inti terdiri dari istri dan kedua putra beliau. Namun demikian, dalam pengambilan keputusan tersebut beliaulah yang mengambil peran utama dalam proses itu.

Tahap kedua dalam proses penyusunan anggaran adalah tahap persiapan anggaran. Dalam tahap mempersiapkan anggaran ini, beliau menyusun menyusun komponenkomponen anggaran yang dibutuhkan dalam konteks pengembangan usaha. Komponenkomponen tersebut nantinya akan menjadi anggaran biaya dalam rangka pengembangan usaha. Komponen anggaran biaya itu meliputi biaya tempat, gerobak, peralatan dan perlengkapan, serta biaya lain-lain.

"Jadi karyawan gajinya diambil dari pendapatan harian. Modal awal hanya untuk beli tanah, bangun pernak-pernik, kemudian perlengkapan, dan barangbarang pecah yang disesuaikan dengan kondisi berkaitan harga jual dan persiapan modal" (Hadi Mulyono, pemilik usaha).

Berdasarkan penyataan beliau tersebut bahwa dalam penentuan komponen anggaran dilakukan penyesuaian dengan kondisi harga jual dan persiapan modal yang telah ditentukan. Artinya, beliau menentukan level kualitas peralatan dan perlengkapan dengan telah menyesuaikan kepada modal yang disediakan.

Berikutnya adalah melakukan tahap penentuan anggaran. Berdasarkan anggaran yang telah disusun, beliau selanjutnya mendiskusikannya dengan keluarga inti. Beliau memiliki prinsip bahwa istri dan kedua putra beliau harus mengetahui segala sesuatu yang berhubungan dengan usaha ini.

"Keluarga inti atau istri dan anak-anak saya yang bertanggungjawab berkaitan apapun. Keluarga inti saya libatkan untuk diskusi dan saya libatkan untuk tau, dan tetap saya yang memutuskan" (Hadi Mulyono, pemilik usaha).

Keterlibatan dalan proses pengambilan keputusan tersebut berlaku juga untuk segala sesuatu yang dibutuhkan dalam konteks pengembangan usaha. Setelah mendiskusikan dengan keluarga inti, dan sesuai dengan modal yang disediakan, serta telah mendapatkan lokasi, beliau kemudian mulai melaksanakan pengembangan usaha.

Tahap akhir dalam proses penyusunan anggaran adalah pelaksanaan anggaran. Berdasarkan hasil wawancara yang dilakukan secara mendalam, pada setiap pelaksanaan pengembangan usaha beliau selalu terlibat langsung di setiap prosesnya.

"Bisa saya bisa karyawan, tergantung kondisi saya ... Yang jelas, semua konsep dari saya dan pengontrolan sesuai yang saya bisa sesuai konsep tradisional saya dan allhamdulilah berjalan lancar ... pelan tapi pasti daripada cepat tidak pasti” (Hadi Mulyono, pemilik usaha).

Sikap keterlibatan ini termasuk saat melakukan transaksi pembelian tempat dan lain-lain. Tetapi jika berada dalam kondisi tidak bisa, beliau meminta karyawan untuk membantu membelikan peralatan mau-pun perlengkapan yang dibutuhkan. Karena beliau terlibat langsung di dalam pelaksanaan pengembangan usaha, maka pengawasannya menjadi lebih terkontrol dan laporan realisasinya pun relatif tidak melenceng dari struktur anggaran yang telah direncanakan sebelumnya. 


\section{Komponen Anggaran dalam Konteks Pengembangan Usaha}

Dalam proses perencanaan pengembangan usaha Bakso dan Mie Ayam Mas Hadi "Asli Solo", Bapak Hadi Mulyono selaku pemilik usaha serta penyusun anggaran hanya menyusun anggaran biaya dalam rangka pengembangan usahanya. Namun demikian, dalam anggaran biaya tersebut beliau tidak menganggarkan gaji karyawan dan biaya bahan baku sebagai komponen anggaran. Hal ini dibuktikan berdasarkan hasil wawancara dengan beliau.

"Jadi karyawan itu gajinya diambil dari pendapatan harian. Modal awal hanya untuk beli tanah, bangun pernak-pernik, kemudian perlengkapan, dan barangbarang pecah yang disesuaikan dengan kondisi berkaitan harga jual dan persiapan modal" (Hadi Mulyono, pemilik usaha)

Berdasarkan hasil wawancara tersebut, penyusunan komponen anggaran biaya yang bisa dipaparkan berdasarkan tiga komponen, yaitu tempat, perlengkapan interior, serta peralatan.

Komponen pertama yang ditekankan pemilik usaha adalah tempat. Tempat usaha yang baik merupakan tempat usaha yang strategis dan mudah dijangkau, baik oleh perusahaan maupun konsumen. Dalam proses penentuan tempat usaha harus juga mempertimbangkan aspek efektifitas dan efisiensi serta sesuai dengan struktur anggaran yang disediakan.

"Kalo di Semarang, manajemen tenaga kerja tidak memadai. Ketok'e ndek kono lebih ayem, karena daerah Karangjati kan daerah pabrik; prospek pembeli banyak disitu” (Hadi Mulyono, pemilik usaha).

Berdasarkan hasil wawancara tersebut bisa diidentifikasi bahwa dalam pemilihan tempat, usaha Bakso dan Mie Ayam Mas
Hadi "Asli Solo" mempertimbangkan lokasi usaha yang strategis namun harus sesuai dengan anggaran yang disediakan. Beliau memilih tempat usaha apabila tempat usaha tersebut strategis dan sesuai dengan anggaran beliau. Namun apabila tempat usaha strategis namun tidak sesuai anggaran, maka beliau memilih untuk mengumpulkan modal terlebih dahulu. Berkaitan dengan anggaran untuk pembelian atau menyewa tempat, beliau membuat anggaran dengan sudah memasukkan unsur pembangunan gedung.

Komponen kedua yang dianalisis adalah perlengkapan interior. Berdasarkan hasil wawancara dengan Bapak Hadi Mulyono, perlengkapan interior yang dimaksud adalah perlengkapan seperti gerobak, meja kursi dan lain-lain. Anggaran yang disediakan beliau sudah ditentukan sesuai dengan acuan harga jual tempat langganan beliau.

Komponen ketiga adalah peralatan. Berdasarkan hasil wawancara dengan Bapak Hadi Mulyono diperoleh informasi bahwa peralatan yang dibutuhkan untuk pengembangan usaha meliputi peralatan produksi, makan dan minum, serta peralatan cuci dan kebersihan. Peralatan produksi yaitu dandang, set lengkap kompor gas, sendok kuah dan lain-lain, untuk peralatan makan dan minum seperti mangkok, gelas, sedotan dan lain-lain. Sedangkan peralatan cuci dan kebersihan terdiri dari tempat cuci, sabun, sapu, tempat sampah dan lain-lain. Anggaran yang disediakan adalah berdasarkan kondisi harga jual saat melakukan pengembangan usaha.

\section{Pembahasan}

Sebuah proses pengembangan usaha tidak terlepas pada rencana yang matang dan dengan anggaran yang tepat guna. Suryati \& Sadjiarto (2018) berdasarkan hasil penelitiannya menemukan bahwa merancang anggaran yang sesuai dengan tujuan perusahaan merupakan unsur yang perlu diperhatikan 
dalam pengembangan usaha. Oleh sebab itu, penyusunan anggaran perlu dilakukan untuk menyesuaikan kebutuhan dalam pelaksanaan pengembangan usaha. Penyusunan anggaran dalam sebuah pengembangan usaha dapat menjadi dasar pemilihan sumber dan investasi dana (Nafarin, 2013; Adhi et al., 2019). Dengan demikian dapat diketahui rincian sumber dan investasi dana maupun batasan dana yang akan dicari dan digunakan. Pemikiran ini diperkuat oleh hasil penelitian yang ditemukan oleh Febrianty (2017) bahwa dengan adanya anggaran, usaha akan mampu memantau pemborosan terhadap hal-hal yang tidak berkaitan dengan strategi bisnisnya. Kondisi itu aka mendorong terwujudnya pengembangan usaha dan mendapatkan hasil yang maksimal.

Pengembangan usaha yang dilakukan oleh Bapak Hadi Mulyono selaku pemilik usaha Bakso dan Mie Ayam Mas Hadi "Asli Solo" teridentifikasi bertujuan memperoleh laba sebanyak-banyaknya serta memperkenalkan kepada masyarakat bahwa produknya merupakan produk yang berkualitas yang diproduksi sendiri tanpa bahan pengawet. Usaha milik Pak Hadi ini tidak memiliki terget waktu dalam pengembangan usahanya. Meskipun demikian, rencana pengembangan usaha tetap ada bahkan sejak pertama kali berjualan keliling hingga sekarang.

Penyusunan anggaran dalam konteks pengembangan usaha Bakso dan Mie Ayam Mas Hadi "Asli Solo" adalah bergantung dengan jumlah modal dan tersedianya lokasi pengembangan usaha. Jumlah modal memiliki hubungan dengan cukup atau tidaknya modal yang ada di tabungan untuk digunakan dalam konteks pengembangan usaha. Apabila modal yang dimiliki masih belum cukup, beliau lebih memilih untuk menambah tabungan modal terlebih dahulu daripada mencari tambahan dana seperti melakukan pinjaman pada bank atau lembaga keuangan lainnya.
Beliau memiliki prinsip bahwa jangan sampai melakukan pinjaman, karena apabila tindakan itu dilakukan maka keuntungan yang diperolehnya harus dibagi untuk mengangsur pinjaman plus bunganya. Pemilik usaha lebh berorientasi bahwa modal yang digunakan dalam pengembangan usaha merupakan modal sendiri yang berasal dari tabungan.

Dalam proses penyusunan anggaran yang dilakukan oleh Bapak Hadi Mulyono dinilai sudah sesuai dengan teori yang dikemukakan oleh Nafarin (2013). Proses penyusunan anggaran menurut Nafarin (2013) meliputi empat tahap, yaitu menentukan pedoman (dasar) anggaran, mempersiapkan anggaran, menentukan anggaran, dan melaksanakan anggaran. Penentuan pedoman anggaran yang dilakukan oleh pemilik usaha memenuhi dua hal yang dianjurkan oleh Nafarin (2013), yaitu menetapkan rencana perusahaan, dan membentuk panitia penyusunan anggaran.

Namun demikian, di dalam tahap persiapan anggaran, Bapak Hadi Mulyono hanya menyusun anggaran biaya. Kondisi ini tidak sesuai konsepsi dari Nafarin (2013) yang menyatakan bahwa dalam mempersiapkan anggaran seharusnya menyusun anggaran baik operasional maupun keuangan. Anggaran operasional meliputi anggaran penjualan, biaya penjualan, biaya produksi, biaya pabrik, dan anggaran laporan laba rugi. Anggaran keuangan terdiri dari anggaran kas, piutang, persediaan, utang, dan anggaran neraca.

Lebih lanjut, hasil analisis penelitian ini menemukan bahwa pemilik usaha dalam tahap penentuan anggaran dan pelaksanaan anggaran telah sesuai dengan tahapan penyusunan anggaran yang dikemukakan oleh Nafarin (2013). Dalam tahap penentuan anggaran, pemilik usaha telah mendiskusikan dan menyesuaian rencana akhir dari setiap komponen anggaran dengan pihak keluarga inti, yaitu istri dan kedua putranya. 
Komponen anggaran yang disusun oleh Bapak Hadi Mulyono adalah anggaran parsial. Menurut Nafarin (2013), anggaran parsial disusun dengan tidak mencakup keseluruhan kegiatan serta kepentingan keuangan. Sementara itu, dalam penyusunan anggaran Bapak Hadi Mulyono hanya menyusun komponen anggaran biaya saja. Hasil penelitian ini tidak relevan dengan temuan penelitian Kristianto (2012) yang menyatakan bahwa menyusun bussines plan dalam konteks pengembangan usaha seharusnya memuat anggaran keuangan meliputi laporan laba rugi, neraca dan aliran kas. Sedangkan menurut Yohanna \& Maya (2018), rencana operasional perusahaan berkaitan dengan kebutuhan anggaran dan pengeluaran operasional perusahaan. Rencana operasional memuat anggaran penjualan, biaya pabrik, biaya usaha, dan anggaran laporan laba rugi.

Dalam perhitungan laba-rugi usaha Bakso dan Mie Ayam Mas Hadi "Asli Solo", Bapak Hadi Mulyono sebagai pemilik menerapkan pola manajemen yang sangat sederhana dimana memperoleh laba diartikan sebagai hasil penjualan saat ini adalah lebih besar dari biaya produksi saat ini. Beliau tidak memperhitungkan nilai biaya produksi secara global pada saat menyusun angaran untuk pengembangan usaha. Selain tidak memperhitungkan laba rugi secara global, beliau juga tidak mempersiapkan penyusunan anggaran bagi gaji karyawan. Selama ini gaji karyawan diambilkan dari pendapatan harian. Jadi keuntungan hari ini merupakan keuntungan untuk karyawan juga. Kondisi ini tidak sesuai hasil temuan penelitian Zuchairima (2010) yang menyatakan bahwa landasan dalam penyusunan anggaran biaya meliputi total biaya dalam pengembangan usaha berdasarkan proyeksi bahan produksi, upah dan biaya overhead pabrik.

Proses penyusunan anggaran yang diterapkan pada usaha Bakso dan Mie Ayam
Mas Hadi "Asli Solo" dinilai belum memadai karena anggaran yang disusun hanyalah anggaran biaya yang tidak lengkap, oleh karena faktor sumber daya manusia pada perusahaannya belum memadai. Selain itu, berdasarkan pengalaman beliau, proses penyusunan anggaran yang sederhana akan minim resiko dan dalam menggunakannya tidak mengalami kerugian. Karena alasan tersebut maka beliau merasa lebih nyaman menggunakan model penyusunan anggaran yang sederhana.

Meskipun demikian, dengan model anggaran biaya tersebut, proses pelaksanaannya dalam konteks pengembangan usaha menjadikan pemilik usaha merasa mampu mengendalikan serta mengawasi sehingga realisasnya relatif tidak melenceng jauh daripada struktur anggaran yang direncanakan. Hasil penelitian ini didukung dengan temuan yang dperoleh Adzim (2017) bahwa anggaran biaya dapat membantu dalam menyediakan informasi biaya dan mengetahui tingkat pencapaian target. Adaya persiapan konsep yang matang juga dinilai mendukung pemilik usaha Bakso dan Mie Ayam Mas Hadi "Asli Solo" mampu mengembangkan usahanya tersebut sehingga menjadi memiliki dua cabang usaha.

\section{SIMPULAN}

Pengembangan usaha Bakso dan Mie Ayam Mas Hadi "Asli Solo" diidentifikasi bertujuan untuk memperoleh laba sebanyakbanyaknya dan memperkenalkan produknya yang tidak menggunakan bahan pengawet kepada masyarakat.

Proses penyusunan dan pelaksanaan anggaran dalam konteks pengembangan usaha Bakso dan Mie Ayam Mas Hadi "Asli Solo" dinilai sudah sesuai dengan empat tahapan penyusunan anggaran. Proses penyusunan dan pelaksanaan anggaran di dalam konteks pengembangan usaha dilaksanakan sesudah 
terkumpulnya modal dan mendapatkan lokasi yang sesuai dengan keinginan dari beliau. Pengembangan usaha beliau tidak memiliki target waktu pelaksanaan. Panitia penyusunan anggaran terdiri dari beliau dan keluarga inti. Dengan proses penyusunan dan pelaksanaan seperti ini maka realisasi anggaran dinilai tidak akan melenceng jauh dari anggaran yang direncanakan.

Anggaran yang disusun oleh pemilik usaha dalam konteks pengembangan usaha hanyalah menyusun anggaran biaya saja. Komponen anggaran biaya itu meliputi lokasi, peralatan maupun perlengkapan. Komponen anggaran pengembangan usaha Bakso dan Mie Ayam Mas Hadi "Asli Solo" belum seluruhnya dianggarkan. Sebagai contoh, anggaran gaji karyawan dan biaya produksi belum dicakup saat pengembangan usaha.

Penulis menyadari adanya keterbatasan penelitian ini terletak pada informasi yang diperoleh menjadi terbatas, dikarenakan untuk menjaga kerahasiaan perusahaan. Hal ini berpengaruh pada pembatasan ruang lingkup penelitian yang tidak membahas realisasi dan evaluasi anggaran pengembangan usaha pada Bakso dan Mie Ayam Mas Hadi "Asli Solo". Berdasarkan keterbatasan itu maka direkomendasikan bagi para peneliti berikutnya untuk melakukan penelitian lanjutan yang lebih mendalam dan terbuka dengan upaya memperluas ruang lingkup penelitian.

\section{REFERENSI}

Adhi, K., Hakim, A., \& Makmur, M. (2019). Proses perencanaan anggaran berbasis kinerja pada Politeknik Pembangunan Pertanian Malang. Jurnal Profit, 13(1), 47-62. doi: 10.21776/ub.profit.2019. 013.01.6.

Adzim, F. (2017). Peranan sistem informasi akuntansi sebagai alat bantu manajemen dalam pengambilan keputusan biaya pada Perusahaan Daerah Air Minum (PDAM) Kota Makassar. Jurnal
Perspektif, 2(1), 173-179. doi: 10. 26618/perspektif.v2i1.433.

Darwanto. (2013). Peningkatan daya saing UMKM berbasis inovasi dan kreativitas (Strategi penguatan property right terhadap inovasi dan kreativitas). Jurnal Bisnis dan Ekonomi (JBE), 20(2), 142149. Retrieved from https://www. unisbank.ac.id/ojs/index.php/fe3/article/ view/3159.

Fatchan, A. (2011). Metode penelitian kualitatif. Jenggala Pustaka Utama.

Febrianty, Z. (2017). Strategi pengembangan usaha dengan menggunakan pendekatan Balanced Scorecard pada CV. Cahaya Anugerah Abadi di Palu. Calyptra: Jurnal Ilmiah Mahasiswa Universitas Surabaya, 6(2), 90-103. Retrieved from https://journal.ubaya.ac.id/index.php/jim us/article/view/901.

Fuad, M., Sudarma, M., \& Irianto, G. (2019). Exploration of obstacles faced by successors in the intergenerational transition process of family business. Journal of Applied Management (JAM), 17(1), 20-29. doi: 10.21776/ub.jam. 2019.017.01.03.

Jannah, S. F. (2017). Strategi pengembangan usaha homemade kefr Khadeejah Rembang. Undergraduate (S1) Thesis. UIN Walisongo.

Kristianto, D. (2012). Menyusun business plan dalam rangka pengembangan usaha. Jurnal Ekonomi dan Kewirausahaan, 12(1), 58-66.

Meiliani, D. (2016). Analisis penyusunan anggaran penjualan pada CV. Usaha Bersama Palembang. Skripsi. Universitas Muhammadiyah Palembang.

Moleong, L. J. (2011). Metodologi penelitian kualitatif. PT. Remaja Rosdakarya.

Nafarin, M. (2013). Penganggaran perusahaan. Salemba Empat.

Rudianto. (2009). Penganggaran. Erlangga.

Sasongko, C., \& Parulian, S. R. (2010). Anggaran. Salemba Empat.

Shalahuddin, I., Maulana, I., \& Eriyani, T. (2018). Prinsip-prinsip dasar kewirausahaan. Deepublish. 
Suci, Y. R. (2017). Perkembangan UMKM (usaha mikro kecil dan menengah) di Indonesia. Cano Ekonomos: Jurnal Ilmiah Fakultas Ekonomi, 6(1), 51-58. Retrieved from https://www.neliti.com/ publications/58432/perkembanganumkm-usaha-mikro-kecil-danmenengah-di-indonesia\#cite.

Sugiyono. (2015). Metode penelitian kombinasi (Mix methods). Alfabeta.

Suhendi \& Sasangka, I. (2014). Pengantar bisnis. Alfabeta.

Suryati, K., \& Sadjiarto, A. (2018). Analisis pengembangan usaha Fanny Cake n' Bakery Salatiga. Jurnal Ecodunamika, 1(3). Retrieved from https://ejournal. uksw.edu/ecodunamika/article/viw/1696
Yohanna, L., \& Maya, S. (2018). Business plan sebagai alternatif strategi pengembangan usaha. Prosiding. Seminar Nasional dan Diskusi Panel Multi disiplin Hasil Penelitian \& Pengabdian kepada Masyarakat, Jakarta, 2 Agustus, 502-506. Retrieved from http:// proceeding.unindra.ac.id/index.php/disp anas2018/article/view/178/64.

Zuchairima. (2010). Analisis anggaran sebagai alat perencanaan dan pengendalian biaya proyek pada PT. Bumi Panggita Handitama Pekanbaru. Skripsi. Fakultas Ekonomi dan Ilmu Sosial Universitas Islam Negeri Sultan Syarif Kasim. 